\title{
Effect of Rice (Oryza sativa L.) Added to Meju (Korean Soybean Koji) Dough on Variation of Nutritional Ingredients and Bacterial Community Diversity in Doenjang (Korean Soybean Paste)
}

\author{
Bo Young Jeon, Doo Hyun Park ${ }^{*}$ \\ Department of Biological Engineering, Seokyeong University, Seoul, South Korea. \\ Email: *baakdoo@skuniv.ac.kr
}

Received May 21 $1^{\text {st }}, 2012$; revised July $2^{\text {nd }}, 2012$; accepted July $9^{\text {th }}, 2012$

\begin{abstract}
In this study, effect of rice added to meju dough was evaluated based on the variation of nutritional ingredients and bacterial community diversity in finished doenjang. The ratio of rice added to meju dough (cooked and crushed soybean before fermentation) was $0,0.2$, and 0.4 based on dry weight. Free amino acids, minerals, polyphenol, and total phenolic compounds relatively decreased by addition of rice. However, 2,2-diphenyl-1-picrylhydrazyl free radical (DPPH) scavenging and ferric ion reduction activity was not influenced. Organic acids, which are fermentation metabolites, significantly increased in proportion to percentage balance of rice. Seven and four volatile compounds (VCs) were detected in doenjang prepared without and with rice, respectively, and contents of VCs were significantly lower in the rice-supplemented doenjang. Bacterial community diversity was significantly increased by addition of rice to meju dough. Rice alters chemical composition, fermentation products, and bacterial diversity, but does not downgrade the nature of doenjang.
\end{abstract}

Keywords: Soybean Koji; Soybean Paste; Rice; Antioxidant Activity; Bacterial Community

\section{Introduction}

Doenjang is a Korean soy paste that has been prepared traditionally by long-term ripening of meju under high salt conditions of about $16 \%-20 \% \mathrm{NaCl}[1]$. Meju has been prepared with only cooked soybean by natural fermentation under open environmental condition. Generally, the quality of meju depend mainly on the microbial community, incubation time, and environmental conditions during fermentation, as the soybean is the principal raw material used in the preparation of meju [2,3]. Practically, the incubation time and environmental conditions for meju fermentation can be mechanically controlled, but fermentation fidelity and efficiency cannot be controlled because microbial communities are naturally and randomly inoculated into meju dough during cultivation. The nutritional constituents of soybean are mainly protein and carbohydrate, which are sufficient for the growth of the bacteria and fungi responsible for meju fermentation [4]. Soybean is composed of greater than $40 \%(\mathrm{w} / \mathrm{w})$ of proteins and greater than $30 \%(\mathrm{w} / \mathrm{w})$ of carbohydrates

"Corresponding author. on the basis of dry weight, and also contains physiologically functional compounds such as polyphenol, total phenolic compounds, isoflavones, vitamin E, saponin, and anthocyanin [5-7]. In various in vitro tests, doenjang extract was reported to possess anticancer, antipostmenopausal, and antiosteoporosis capabilities [8,9].

Rice is a major crop that has been used as staple food. Its consumption has been actively encouraged because of its overproduction in Korea. Rice has long been a very popular material for processed and fermented foods including cake, syrup, sweet drinks, cookies, vinegar, and makgeolli $[10,11]$. Especially, rice has been used as a main material with hot pepper and meju in the preparation of gochujang (Korean red pepper paste), in which rice is used as carbohydrate source for fermentation. Rice contains $>90 \%(\mathrm{w} / \mathrm{w})$ of starch and about $8 \%$ of protein on the basis of dry weight. This protein composition is too low to enable rice to be used for meju preparation. Rice is enriched in selenium, niacin, pantothenic acid, vitamin B6, and folate (vitamin B9), compared to soybean [12]. Accordingly, the addition of rice to meju dough may be a factor to improve the quality of doenjang; 
the increase in the percentage balance of carbohydrate might cause the fermentation metabolism to be activated, which could enrich the diversity of the microbial community diversity $[13,14]$.

In this study, three different doenjang preparations were prepared from mejus fermented with soybean or a mixture of soybean and rice by using traditional technique. The effect of rice added to meju dough was evaluated based on the variation of nutritional ingredients and bacterial community diversity in doenjang. The goal was to provide a new recipe for the preparation of rice-supplemented doenjang to increase consumer consumption of rice.

\section{Materials and Methods}

\subsection{Meju Preparation}

Aspergillus oryzae var. oryzae (KACC44848) was cultivated in broth medium at $25^{\circ} \mathrm{C}$ and $150 \mathrm{rpm}$ for $5-7$ days until the ball-shaped hyphae cluster completely occupied the volume of the medium. The broth medium was composed of $10 \mathrm{~g} / \mathrm{L}$ soluble starch (Duksan, Korea), $5 \mathrm{~g} / \mathrm{L}$ soy protein isolate (Nanyung Commercial Co., Korea), 1 g/L yeast extract (Difco, USA) and $1000 \mathrm{ml}$ tap water. The cluster was used as an inoculum for meju fermentation. The dough used to prepare meju was comprised of the following ingredients (mixed ratio) based on dry weight: $100 \%(\mathrm{w} / \mathrm{w})$ soybean (SB-meju), a mixture of $80 \%(\mathrm{w} / \mathrm{w})$ soybean and $20 \%(\mathrm{w} / \mathrm{w})$ rice $(0.8 \mathrm{SB}-$ $0.2 \mathrm{R}-\mathrm{meju})$, or a mixture of $60 \%(\mathrm{w} / \mathrm{w})$ soybean and $40 \%$ $(\mathrm{w} / \mathrm{w})$ rice $(0.6 \mathrm{SB}-0.4 \mathrm{R}-\mathrm{meju})$. Soybean (traditional market, Korea) and rice (traditional market, Korea) soaked in tap water for $24 \mathrm{~h}$ were steamed for $120 \mathrm{~min}$ and then cooled at room temperature. Five hundred milliliters of the ball-shaped A. oryzae hyphae cluster was inoculated into $5 \mathrm{~kg}$ of the cooked meju dough on a dry weight basis, crushed with a stone mortar and then cast into frame (polypropylene; $250 \mathrm{~mm}$ diameter $\times 50 \mathrm{~mm}$ height) to prepare the meju dough. The dough containing A. oryzae hyphae and natural microorganisms was placed on a wood plate with latticed grooves $(10 \times 10 \mathrm{~mm})$ and was incubated at $25^{\circ} \mathrm{C}$ at constant humidity for 7 days. The finished meju was then exposed to sunlight to complete drying.

\subsection{Doenjang Preparation}

The dried meju was crushed to lower than 50 meshes with a stone mortar and put in a glass jar with an airing cap. Brine $(20 \% \mathrm{w} / \mathrm{v})$ prepared with sun-dried salt (traditional market, Korea) was added. The ratio of brine to meju was 3.0 based on weight, which completely wetted the meju. The upper surface of the meju in the glass jar was exposed to sunlight for more than $6 \mathrm{~h}$ per day each day until the upper surface was completely dry; this took about 2 weeks. The dried skin-like cover completely blocked fungal contamination and moisture evaporation. The prepared meju was ripened for 10 months at $20^{\circ} \mathrm{C}$ $25^{\circ} \mathrm{C}$. The finished product represented SB-, $0.8 \mathrm{SB}-0.2 \mathrm{R}-$, and $0.6 \mathrm{SB}-0.4 \mathrm{R}$-doenjangs were obtained.

\subsection{Statistical Analysis}

All of numerical data were obtained by triply repeated tests, analysis, and experiments. Mean values and standard deviations were calculated using SigmaPlot version 11 (Systat Software Inc., USA; http://www.systat.com).

\subsubsection{Analysis of Free Amino Acids}

Samples for mineral analysis were prepared from lyophilized doenjang as described previously $[15,16]$. The extract prepared for free amino acid analysis was directly injected into an automatic amino acid analyzer (S433 model, Sykam, GmbH, Eresing, Germany) equipped with an ammonia filtration column (LCA, k04/Na, $4.6 \times 100$ $\mathrm{mm}$; Sykam, GmbH, Eresing, Germany). Free amino acid content was determined based on the peak area obtained with standard materials and dilution ratio.

\subsubsection{Analysis of Organic Acid}

Lyophilized doenjang was diluted 10 -fold with pure water and incubated in reciprocal shaker at $200 \mathrm{rpm}$ and $4^{\circ} \mathrm{C}$ for $24 \mathrm{~h}$. The doenjang slurry was centrifuged at 10,000 $\times \mathrm{g}$ and $4^{\circ} \mathrm{C}$ for $40 \mathrm{~min}$. The properly diluted and filtrated supernatant was directly injected into injector of high performance liquid chromatography (Gold apparatus, Beckman, Coulter, Brea, CA, USA) equipped with a Shodex Rspak KC-811 ion exclusion column (Showa Denko, Tokyo, Japan) and a model RI-101 refractive index detector (Showa Denko). The organic acids were calculated based on the peak area obtained with standard materials and dilution ratio.

\subsubsection{Analysis of Mineral}

Samples for mineral analysis were prepared from lyophilized doenjang as described previously [17]. Mineral content was analyzed using inductively coupled plasma (ICP) optic emission spectrometry (SPECTRO Analytical Instruments, Kleve, Germany). The extract prepared for mineral analysis was directly injected into the ICP injector under specific wavelengths for $\operatorname{Mg}(279.079 \mathrm{~nm})$, $\mathrm{Na}(589.592 \mathrm{~nm}), \mathrm{K}(766.491 \mathrm{~nm}), \mathrm{Ca}(396.847 \mathrm{~nm}), \mathrm{Mn}$ $(257.610 \mathrm{~nm}), \mathrm{Zn}(213.856 \mathrm{~nm}), \mathrm{Al}(167.080 \mathrm{~nm}), \mathrm{Cu}$ $(324.745 \mathrm{~nm})$, and Fe $(238.204 \mathrm{~nm})$. The mineral concentrations were calculated based on the absorbance obtained with standard materials (AccuTrace Reference 
Standard; AccuStandard, New Haven, CT, USA) and dilution ratio.

\subsubsection{Determination of Antioxidative Compounds and Activity}

Samples were prepared by same method employed for organic acid analysis. The properly diluted supernatant was used to analyze the antioxidative compounds (polyphenol and total phenolic compounds) and activity. Polyphenol content was assessed using the Prussian blue spectrophotometric method [18]. Content of total phenolic compounds were determined via the Folin-Ciocalteu colorimetric method [19]. DPPH radical scavenging activity of doenjang was determined using a modified version of a method developed previously [20]. Ferric ion reduction activity of doenjang was determined by ferrous ion-ferrozine complex reaction. The supernatant $(3.8 \mathrm{~mL})$ was mixed with $50 \mu \mathrm{L}$ of $10 \mathrm{mM} \mathrm{FeCl} \cdot 4 \mathrm{H}_{2} \mathrm{O}$ and incubated for $30 \mathrm{~min}$ at room temperature. Then, $150 \mu \mathrm{L}$ of 5 $\mathrm{mM}$ Ferrozine was added to the mixture and shaken gently. After $10 \mathrm{~min}$, the amount of $\mathrm{Fe}^{2+}$ was monitored by measuring the formation of ferrous ion-ferrozine complex at $562 \mathrm{~nm}$. The concentrations of antioxidative compounds and activity were determined based on absorbance obtained with standard materials and the dilution ratio.

\subsubsection{Analysis of Volatile Compound}

Samples were directly extracted from the lyophilized doenjang $(10 \mathrm{~g})$ with methyl acetate $(25 \mathrm{~mL})$, and the extraction process was repeated three times for single doenjang samples. Extracts obtained via triple extraction were mixed together and adjusted to a final volume of $100 \mathrm{~mL}$ by adding fresh methyl acetate. Two microliters of solvent extract was subsequently injected into the gas chromatography (GC) injector in splitless mode. The 11 volatile compounds that were analyzed were 2-methyl-1butanol, 3-methylbutanol, propionic acid, furfuryl alcohol, 4-hydroxy-2,5-dimethyl-3(2H)-furanone (HDMF), 4-hydroxy-2-ethyl-5-methyl furan-3-one (HEMF), methionol, 2-phynlehanol, 2-methyl-propanol, 1-butanol, 4ethylguaiacol, and 4-hydroxy-2-methylene-5-methyl-3 (2H)-furanone (HMMF). Analyses were performed using a model CP-3800instrument (Varian, Palo Alto, CA, USA) and a Saturn 2100D GC/mass spectrometry (MS) apparatus equipped with a HP-INNOWAX capillary column (Agilent Technologies, Santa Clara, CA, USA) and an FI detector (Varian). Injector and detector temperatures were adjusted to $230^{\circ} \mathrm{C}$ and $260^{\circ} \mathrm{C}$, respectively. Initial oven temperature was maintained at $50^{\circ} \mathrm{C}$ for 5 min and then gradually increased to $230^{\circ} \mathrm{C}$ at a rate of $10^{\circ} \mathrm{C} / \mathrm{min}$. The concentrations of volatile compounds were determined based on peak area obtained with stan- dard materials and the dilution ratio.

\subsection{Temperature Gradient Gel Electrophoresis (TGGE)}

Microbial DNA was directly extracted from the finished doenjang using a Power Soil DNA Isolation kit (MoBio Laboratories, Carlsbad, CA, USA) and a FastPrep-24 bead beater (MoBio). 16S- or 18S-rDNA was amplified using the DNA extracted from the doenjang. A variable region of 16S-rDNA was amplified with the forward primer (eubacteria V3 region, 341f 5'-CCTACGGGAGG CAGCAG-3') and the reverse primer (universal V3 region, 518r 5'-ATTACCGCGGCTGCTGG-3'). A GC clamp (5'-CGCCCGCCGCGCGCGGCGGGCGGGGCG GGGGCACGGGGGGCCTACGGGAGGCAGCAG-3') was attached to the 5'-end of the GC341f primer [21]. A variable region of $18 \mathrm{~S}-\mathrm{rDNA}$ was amplified with the forward primer (EF3 5'-TCCTCTAAATGACCAAGTT TG-3') and the reverse primer (EF4 5'-GGAAGGGRTGT ATTTATTAG-3'). A GC clamp (5'-CGCCCGCCGCGC GCGGCGGGCGGGGCGGGGGCACGGGGGGG-3') was attached to the 5'-end of NS-3 (5'-GCAAGTCTGGT GCCAGCAGCC-3'). TGGE was performed using techniques and procedures employed previously [22] with a Dcode universal mutation detection system (Bio-Rad, Hercules, CA, USA) operated according to the manufacturer's specifications.

\subsection{Identification of TGGE Band}

DNA was extracted from the TGGE band and purified with a DNA Gel Purification kit (Accuprep, Bioneer, Daejeon, Korea). The purified DNA was subsequently amplified with the same primers and procedures employed for TGGE sample preparation, except that the GC clamp was not attached to the forward primer. The species-specific identities of the amplified 16S-rDNA variable region were determined based on sequence homology using the GenBank database system.

\section{Results}

\subsection{Free Amino Acids in Doenjang}

Free amino acids contained in doenjang may be produced by hydrolysis of proteins contained in soybean and rice. Accordingly, contents of free amino acids in doenjang have to be proportional to the percentage balance of soybean and rice. However, the content of free amino acids precisely measured with SB-, 0.8SB-0.2R-, and $0.6 \mathrm{SB}-0.4 \mathrm{R}$-doenjang was not strictly proportional to the percentage balance of soybean and rice as shown in Table 1. Adding $20 \%$ and $40 \%(\mathrm{w} / \mathrm{w})$ of rice to meju dough produced a decrease in amino acid production of about 
Table 1. Free amino acid (FAA) contents in doenjang made of SB-, 0.8SB-0.2R-, 0.6SB-0.4R-meju.

\begin{tabular}{|c|c|c|c|}
\hline Amino acids (\%) & SB & $0.8 \mathrm{SB}-0.2 \mathrm{R}$ & $0.6 \mathrm{SB}-0.4 \mathrm{R}$ \\
\hline Asp & 0.47 & 0.46 & 0.46 \\
\hline Thr & 0.22 & 0.21 & 0.23 \\
\hline Ser & 0.29 & 0.28 & 0.29 \\
\hline Glu & 0.97 & 0.98 & 0.94 \\
\hline Pro & 0.23 & 0.24 & 0.22 \\
\hline Gly & 0.17 & 0.16 & 0.15 \\
\hline Ala & 0.31 & 0.30 & 0.30 \\
\hline Cys & 0.06 & 0.06 & 0.05 \\
\hline Val & 0.35 & 0.33 & 0.36 \\
\hline Met & 0.08 & 0.08 & 0.09 \\
\hline Ile & 0.27 & 0.28 & 0.26 \\
\hline Leu & 0.43 & 0.42 & 0.40 \\
\hline Tyr & 0.14 & 0.13 & 0.15 \\
\hline Phe & 0.25 & 0.22 & 0.23 \\
\hline His & 0.14 & 0.13 & 0.12 \\
\hline Lys & 0.33 & 0.32 & 0.31 \\
\hline Arg & 0.42 & 0.41 & 0.38 \\
\hline Total & 5.13 & 5.01 & 4.94 \\
\hline Ratio of FAA to SB & 5.13 & 6.26 & 8.23 \\
\hline
\end{tabular}

$2.3 \%$ and $3.7 \%$ in $0.8 \mathrm{SB}-0.2 \mathrm{R}$ - and $0.6 \mathrm{SB}-0.4 \mathrm{R}-\mathrm{doen}-$ jang, respectively, in comparison of those in the SBdoenjang.

\subsection{Minerals in Doenjang}

Both soybean and rice contain $\mathrm{Mg}, \mathrm{K}, \mathrm{Ca}, \mathrm{Mn}, \mathrm{Fe}, \mathrm{Zn}$, and $\mathrm{Cu}$, whose contents are significantly or a little higher in soybean than rice [12]. Accordingly, the minerals contained in the doenjang may be proportional to the percentage balance of soybean and rice because minerals themselves contained in soybean and rice become ingredients of doenjang. Contents of all minerals in 0.8SB$0.2 \mathrm{R}$ - and $0.6 \mathrm{SB}-0.4 \mathrm{R}$-doenjang were commonly lower than those in SB-doenjang, which was proportional to the theoretical value as shown in Table 2 .

\subsection{Organic Acids in Doenjang}

The ratio of carbohydrate to protein in SB-, 0.8SB-0.2R-, and $0.6 \mathrm{SB}-0.4 \mathrm{R}-\mathrm{meju}$ was about $0.88,1.37$, and 2.10, respectively, which was arithmetically calculated based
Table 2. Mineral contents in doenjang made of SB-, 0.8SB0.2R-, 0.6SB-0.4R-meju.

\begin{tabular}{|c|c|c|c|}
\hline $\begin{array}{l}\text { Minerals } \\
(\mathrm{mg} / \mathrm{Kg})\end{array}$ & SB & $0.8 \mathrm{SB}-0.2 \mathrm{R}$ & $0.6 \mathrm{SB}-0.4 \mathrm{R}$ \\
\hline $\mathrm{Na}$ & $153,886 \pm 1041$ & $152,542 \pm 1018$ & $153,217 \pm 1191$ \\
\hline $\mathrm{Mg}$ & $2680 \pm 28$ & $2245 \pm 21$ & $2010 \pm 26$ \\
\hline $\mathrm{K}$ & $22,644 \pm 152$ & $20,248 \pm 163$ & $19,777 \pm 144$ \\
\hline $\mathrm{Ca}$ & $3077 \pm 122$ & $2697 \pm 85$ & $2360 \pm 91$ \\
\hline $\mathrm{Mn}$ & $9.03 \pm 0.58$ & $8.58 \pm 0.48$ & $8.15 \pm 0.35$ \\
\hline $\mathrm{Fe}$ & $171.7 \pm 9.1$ & $152.5 \pm 7.8$ & $128.2 \pm 6.5$ \\
\hline $\mathrm{Zn}$ & $11.21 \pm 0.31$ & $10.24 \pm 0.24$ & $9.37 \pm 0.24$ \\
\hline $\mathrm{Cu}$ & $3.4 \pm 0.1$ & $3.2 \pm 0.1$ & $3.0 \pm 0.1$ \\
\hline $\begin{array}{l}\mathrm{Ni}, \mathrm{Cd}, \mathrm{Cr}, \\
\mathrm{Hg}, \mathrm{La}, \mathrm{Pb}, \\
\mathrm{Sb}, \mathrm{Sn}, \mathrm{Ti}\end{array}$ & N.D & N.D & N.D \\
\hline
\end{tabular}

on the nutritional ingredients of soybean and rice [12]. The organic acids contained in doenjang may be generated from carbohydrates (sugars) by microbial fermentation metabolism. Accordingly, organic acid production may be increased in proportion to the percentage balance of carbohydrate during the fermentation of meju or the ripening of doenjang. Citric, malic, succinic, lactic, and acetic acid production significantly increased in proportion to rice contents but pyroglutamic acid production was not influenced by rice addition as shown in Table 3.

\subsection{Antioxidative Compound and Activity of Doenjang}

Soybean and rice pericarp contains various antioxidative compounds including polyphenols, total phenolic compounds, tannin, or proanthocyanidin, while rice lacks the antioxidative compounds [23]. Microorganisms responsible for meju fermentation are unable to produce polyphenol and total phenolic compounds [24,25]. Accordingly, polyphenol and total phenolic compounds in doenjang originate from soybean. Presently, the contents of polyphenol and total phenolic compounds in doenjang were proportional to the percentage balance of soybean, but the activities of DPPH scavenging and ferric ion reduction of doenjang were not influenced by addition of rice as shown in Table 4.

\subsection{Volatile Compounds in Doenjang}

Eleven volatile compounds were quantitatively and qualitatively analyzed. Seven were identified in the SBdoenjang and four were commonly identified in both the 0.8SB-0.2R- and 0.6SB-0.4R-Doenjang. 2-Methyl-1butanol, HEMF, and 4-EG were not produced and the 
Table 3. Organic acid contents in doenjang made of SB-, 0.8SB-0.2R-, 0.6SB-0.4R-meju.

\begin{tabular}{cccc}
\hline $\begin{array}{c}\text { Organic acids } \\
(\mathrm{mg} / \mathrm{Kg})\end{array}$ & $\mathrm{SB}$ & $0.8 \mathrm{SB}-0.2 \mathrm{R}$ & $0.6 \mathrm{SB}-0.4 \mathrm{R}$ \\
\hline Citric acid & $12,375 \pm 248$ & $13,478 \pm 326$ & $14,294 \pm 166$ \\
Malic acid & $14,766 \pm 587$ & $15,566 \pm 462$ & $16,197 \pm 432$ \\
Succinic acid & $732 \pm 48$ & $1132 \pm 65$ & $1434 \pm 77$ \\
Lactic acid & $650 \pm 26$ & $875 \pm 43$ & $1148 \pm 37$ \\
Acetic acid & $608 \pm 34$ & $731 \pm 47$ & $826 \pm 42$ \\
$\begin{array}{c}\text { Pyroglutamic } \\
\text { acid }\end{array}$ & $1202 \pm 82$ & $1244 \pm 57$ & $1193 \pm 53$ \\
\hline
\end{tabular}

Table 4. Antioxidative compounds and activity in doenjang made of SB-, 0.8SB-0.2R-, 0.6SB-0.4R-meju.

\begin{tabular}{cccc}
\hline $\begin{array}{c}\text { Antioxidative } \\
\text { compounds (mg/Kg) }\end{array}$ & SB & $0.8 \mathrm{SB}-0.2 \mathrm{R}$ & $0.6 \mathrm{SB}-0.4 \mathrm{R}$ \\
\hline Polyphenol & $4265 \pm 147$ & $3335 \pm 131$ & $2690 \pm 142$ \\
$\begin{array}{c}\text { Total phenolic } \\
\text { compounds }\end{array}$ & $6243 \pm 352$ & $4959 \pm 247$ & $3889 \pm 129$ \\
$\begin{array}{c}\text { DPPH scavenging } \\
\text { activity } \\
\begin{array}{c}\text { Reduction activity } \\
\text { of } \mathrm{Fe}^{3+} \text { to Fe }\end{array}\end{array}$ & $2222 \pm 101$ & $2270 \pm 99$ & $2309 \pm 116$ \\
\hline
\end{tabular}

production of 3-methylbutanol, propionic acid, and furfuryl alcohol commonly decreased by the rice addition to the meju dough as shown in Table 5.

\subsection{Bacterial Community Variation in Doenjang}

16S-rDNA was normally amplified but 18 S-rDNA was not. This may reflect the maintenance or growth of specific bacteria during meju fermentation and doenjang ripening, while fungal hyphae may lose their physiological activity. The number of DNA bands detected in the TGGE gels for SB-doenjang was more than 50\% lower than that for SB-R-doenjang, and the TGGE patterns for $0.8 \mathrm{SB}-0.2 \mathrm{R}$ - and $0.6 \mathrm{SB}-0.4 \mathrm{R}$-doenjang were completely identical with each other as shown in Figure 1. Bacteria belonged to Bacillus genus were commonly identified in all doenjang preparations [26-28]. In addition, bacteria of the genera Staphylococcus and Virgibacillus were commonly identified in $0.8 \mathrm{SB}-0.2 \mathrm{R}$ - and $0.6 \mathrm{SB}-0 . \mathrm{R}-$ doenjang as shown in Table 6.

\section{Discussion}

The quality of doenjang can be evaluated based on the contents of various nutritional ingredients that include free amino acids, organic acids, volatile compounds, minerals, fatty acids, and antioxidative compounds [29, 30]. Free amino acids, volatile compounds, and organic acids are biochemically produced by microorganisms responsible for meju fermentation. However, antioxidative compounds (polyphenol and total phenolic compounds) and minerals originated from the soybean ingredient. Practically, contents of free amino acids and organic acids measured for 15 doenjang preparations were markedly varied from $1.70 \%$ to $5.36 \%$ and from $0.5 \%$ to $1.65 \%$, respectively. Meanwhile, the contents of polyunsaturated fatty acids and unsaturated fatty acids measured based on area\% were slightly varied from $51.52 \%$ to $64.91 \%$ and from $82.28 \%$ to $85.22 \%$, respectively [31]. Variations of the free amino acid contents were greatly higher than those of fatty acids, considering that variation of contents of crude protein and lipid were from $11.8 \%$ to $16.8 \%$ and from $7.1 \%$ to $8.6 \%$, respectively, in 15 doenjang preparations. This indicates that contents of microbial metabolites in doenjang may be an index to evaluate doenjang quality because those are produced depending on metabolic and physiological activity of microorganisms responsible for meju fermentation. Accordingly, the effect of rice on doenjang quality may be evaluated on the basis of the biochemical metabolites contained in doenjang. However, the chemical ingredients originating

Table 5. Volatile organic compounds in doenjang made of SB-, 0.8SB-0.2R-, 0.6SB-0.4R-meju.

\begin{tabular}{|c|c|c|c|c|}
\hline Volatile compounds (mg/kg) & SB & $0.8 \mathrm{SB}-0.2 \mathrm{R}$ & $0.6 \mathrm{SB}-0.4 \mathrm{R}$ & General properties \\
\hline 2-methyl-1-butanol & $0.19 \pm 0.03$ & 0.0 & 0.0 & Organic solvent, odor \\
\hline 3-methylbutanol & $1.92 \pm 0.3$ & $0.46 \pm 0.03$ & $0.48 \pm 0.03$ & Strong fragrant of peppermint or camphor \\
\hline Propionic acid & $5.78 \pm 0.2$ & $2.77 \pm 0.2$ & $2.99 \pm 0.1$ & Off-flavor (odor) for wine \\
\hline Furfuryl alcohol & $21.59 \pm 1.1$ & $17.29 \pm 0.8$ & $15.97 \pm 0.8$ & Caramel, sweet, woody flavor \\
\hline HDMF & $1.69 \pm 0.2$ & $0.6 \pm 0.01$ & $0.7 \pm 0.01$ & Caramel-like smelling \\
\hline HEMF & $0.41 \pm 0.04$ & 0.0 & 0.0 & Caramel-like smelling \\
\hline 4-EG & $0.59 \pm 0.02$ & 0.0 & 0.0 & Bacon, spice, clove, smoky aroma \\
\hline
\end{tabular}


Table 6. The homologous bacteria with DNAs extracted from the numbered bands in TGGE gel were arranged in the order of the band numbers in Figure 1.

\begin{tabular}{|c|c|c|c|}
\hline \multirow{2}{*}{$\begin{array}{l}\text { Band } \\
\text { No. }\end{array}$} & \multicolumn{3}{|c|}{ Lanes in TGGE of DNA obtained from Doenjang } \\
\hline & 1 (DFS) & $2(0.8 \mathrm{DFS}-0.2 \mathrm{R})$ & $3(0.6 \mathrm{DFS}-0.4 \mathrm{R})$ \\
\hline 1 & Bacillus mycoides & Bacillus sp. & Bacillus sp. \\
\hline 2 & Bacillus subtilis & $\begin{array}{c}\text { Bacillus } \\
\text { panaciterrae }\end{array}$ & $\begin{array}{l}\text { Staphylococcus } \\
\text { succinus }\end{array}$ \\
\hline 3 & Bradyrhizobium sp. & Bacillus subtilis & $\begin{array}{c}\text { Bacillus } \\
\text { panaciterrae }\end{array}$ \\
\hline 4 & $\begin{array}{c}\text { Bacillus } \\
\text { amyloliquefaciens }\end{array}$ & $\begin{array}{c}\text { Staphylococcus } \\
\text { xylosus }\end{array}$ & Bacillus subtilis \\
\hline 5 & $\begin{array}{c}\text { Bacillus } \\
\text { licheniformis }\end{array}$ & Virgibacillus sp. & $\begin{array}{c}\text { Staphylococcus } \\
\text { xylosus }\end{array}$ \\
\hline 6 & - & Bacillus subtilis & Virgibacillus sp. \\
\hline 7 & - & $\begin{array}{c}\text { Bacillus } \\
\text { licheniformis }\end{array}$ & Bacillus subtilis \\
\hline 8 & - & Bacillus sp. & $\begin{array}{c}\text { Bacillus } \\
\text { licheniformis }\end{array}$ \\
\hline 9 & - & $\begin{array}{c}\text { Bacillus } \\
\text { amyloliquefaciens }\end{array}$ & Bacillus sp. \\
\hline 10 & - & $\begin{array}{l}\text { Uncultured } \\
\text { bacterium }\end{array}$ & $\begin{array}{c}\text { Bacillus } \\
\text { amyloliquefaciens }\end{array}$ \\
\hline 11 & - & - & $\begin{array}{l}\text { Uncultured } \\
\text { bacterium }\end{array}$ \\
\hline
\end{tabular}

from soybean and rice must be analyzed for comparison of the nutritional value of rice-supplemented doenjang.

Adding rice to the dough used in the preparation of meju may alter the percentage balance of organic carbon and nitrogen sources for microbial growth. A prior study reported protein contents in SB-, 0.8SB-0.2R-, and $0.6 \mathrm{SB}-0.4 \mathrm{R}-\mathrm{meju}$ to be about $40 \%, 34 \%$, and $27 \%(\mathrm{w} / \mathrm{w})$, respectively, and carbohydrate contents to be about $35 \%$, $46 \%$, and $57 \%(\mathrm{w} / \mathrm{w})$, respectively [12]. These contents are 5 - 8 times higher than the total free amino acids (Table 1) and 11 - 15 times higher than the total organic acids (Table 3) in doenjang. The higher and appreciably higher ratios of free amino acids and organic acids to soybean content, respectively, in SB-R-doenjang as compared with SB-doenjang is a clue that that rice addition to meju dough may not be a cause to limit protein content for free amino acid production but may be a factor to activate microbial metabolism for fermentation of organic acids [32]. The present observation of higher bacterial diversity in SB-R-doenjang than in SB-doenjang (Figure 1 and Table 6) is another clue that the rice addition to meju dough be a factor to nutritionally activate bacterial growth and ecologically increase bacterial diversity [33]. Increase of bacterial diversity may cause to

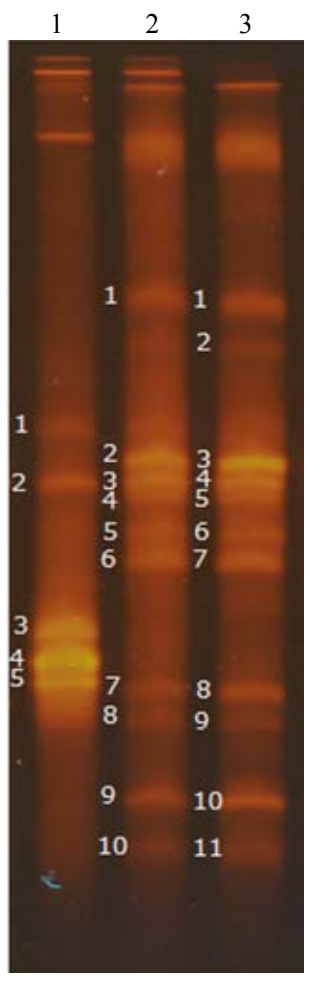

Figure 1. TGGE pattern of 16S-rDNA variable region amplified with genomic DNA extracted from doenjang made of DFS- (1), DFS-0.2R- (2), DFS-0.4R-meju (3).

increase specific metabolites in fermenting meju and ripening doenjang, resulting in the increased ratios of free amino acids and organic acids to soybean content, while the production of volatile compounds may be limited or inhibited [34]. Certain volatile compounds that cause fragrant flavors and off-flavors may be generated by biochemical conversion of amino acids and metabolic fermentation of sugars during meju fermentation. Increase of the percentage balance of carbohydrate in meju dough may induce the active microbial catabolism of carbohydrates while limiting the catabolism of protein. As a consequence, off-flavors or unwanted flavors (such as peppermint, caramel, bacon, spice, camphor, sweet, and smoky) for doenjang may be produced in limited quantity. Contents of free amino acids and organic acids, especially, citric and lactic acid, are major factors to the improved taste and nutrients of doenjang [35]. Volatile compounds, such as 2-methyl-1-butanol, HEMF, 4-EG, 3-methylbutanol, propionic acid, furfuryl alcohol, and HDMF detected in SB- and SB-R-doenjang are improper or unwanted factors for doenjang [36,37]. Accordingly, it can be suggested that the addition of $20 \%-40 \%(\mathrm{w} / \mathrm{w})$ rice to meju dough may induce nutritional conditions that are favorable for bacterial growth and fermentation, with consequent improvement of doenjang quality.

Generally, minerals including $\mathrm{Mg}, \mathrm{Ca}, \mathrm{Mn}, \mathrm{Fe}, \mathrm{Zn}$, 
and $\mathrm{Cu}$, and antioxidative compounds including polyphenol and total phenolic compounds [12] contained in soybean and rice become chemical ingredients of doenjang. Adding rice to meju dough was a cause the minerals and the antioxidative compounds to be maximally $30 \%$ and $40 \%$ decreased, respectively, in proportion to the percentage balance of soybean and rice. However, nature of doenjang may be not influenced by the reduction of the minerals and the antioxidative compounds because doenjang has not been used as mineral source for nutritional requirement or as antioxidant for functional reinforcement of food but has been used as a sauce for seasoning to taste of various foods. Generally, doenjang quality may be commercially fortified by the supplementation or content of antioxidative compounds [38,39]. From the nutritional standpoint, polyphenol and total phenolic compounds contained in doenjang may be helpful for the long-term preservation of foods, which may be substituted by other antioxidative compounds biochemically generated by microorganisms responsible for meju preparation and ripening of doenjang, considering that the antioxidative activity (DPPH scavenging and ferric ion reduction activity) was not decreased by addition of rice and was not proportional to the contents of the antioxidative compounds in doenjang. It is very possible that various metabolic intermediates, reduced metabolites, and coenzymes originating from chemically or biochemically lysed microbial cells can function as antioxidative agents, which may be proportional to biomass and diversity of microorganisms [40].

\section{Conclusion}

Rice may be useful as a supplement for meju dough when evaluated on the basis of free amino acid production, organic acid production, volatile compounds, and bacterial community diversity. Especially, DPPH scavenging and ferric ion reduction activity of doenjang may possibly be intimately related to the rice addition because the proper environmental conditions for bacterial growth may induce increased bacterial community diversity and activated bacterial physiology. The environmental condition of doenjang may be converted to the biophile condition. Positive interrelationship between bacteria and doenjang condition may be a factor to improve doenjang quality by activation of fermentation metabolism or enzymatic reaction. The use of rice in meju preparation may be helpful to activate rice consumption and improve doenjang quality, because the fermentation and ripening process may positively influenced by the chemical and nutritional balance between protein and carbohydrate. Especially, a maximum of $40 \%(\mathrm{w} / \mathrm{w})$ rice may be substituted for soybean in the meju process according to the comparable quality of SB-, $0.8 \mathrm{SB}-0.2 \mathrm{R}-$, and $0.6 \mathrm{SB}-0.4 \mathrm{R}-$ doenjang.

\section{Acknowledgements}

This research was supported by Seokyeong University in 2009.

\section{REFERENCES}

[1] K. Y. Park and K. O. Jung, "Fermented Soybean Products as Functional Foods: Functional Properties of Doenjang (Fermented Soybean)," In: J. Shi, C. T. Ho and F. Shahidi, Eds., Asian Functional Foods, CRC Press, Boca Raton, 2005, pp. 555-596. doi:10.1201/9781420028119.ch20

[2] S. S. Kim, "Effect of Meju Shapes and Strains on the Quality of Commercial Soy Sauce," Korean Journal of Food Science and Technology, Vol. 10, 1978, pp. 63-72.

[3] J. W. Kim, Y. S. Kim, P. H. Jeong, H. E. Kim and D. H. Shin, "Physicochemical Characteristics of Traditional Fermented Soybean Products Manufactured in Folk Villages of Sunchang Region," Journal of Food Hygiene and Safety, Vol. 21, No. 2, 2006, pp. 223-230.

[4] I. J. Kim, J. K. Lee, M. H. Park, D. H. Shon, C. H. Rye and Y. L. Ha, "Preparation Method of Meju by Three Step Fermentation," Korean Journal of Food Science Technology, Vol. 34, 2002, pp. 536-539.

[5] M. Miyazawa, K. Sakano, S. Nakamura and H. Kosaka, "Antimutagenic Activity of Isoflavones from Soybean Seeds (Glycine max Merrill)," Journal of Agricultural and Food Chemistry, Vol. 47, No. 4, 1999, pp. 13461349. doi: $10.1021 / \mathrm{jf} 9803583$

[6] A. Cardador-Martinez, E. Castano-Tostado and G. LoarcaPina, "Antimutagenic Activity of Natural Phenolic Compounds Present in the Common Bean (Phaseolus vulgaris) against Aflatoxin B1," Food Additives and Contamitant, Vol. 19, No. 1, 2002, pp. 62-69. doi:10.1080/02652030110062110

[7] Y. Jing and S. Waxman, "Structural Requirements for Differentiation-Induction and Growth Inhibition of Mouse Erythroleukemia Cells by Isoflavones," Anticancer Research, Vol. 15, No. 4, 1995, pp. 1147-1152.

[8] C.D. Allred, K. F. Allred, Y. H. Ju, T. S. Goeppinger, D. R. Doerge and W. G. Helferich, "Soy Processing Influences Growth of Estrogen Dependent Breast Cancer Tumors," Carcinogenesis, Vol. 25, 2005, pp. 1649-1657. doi:10.1093/carcin/bgh178

[9] K. M. Hwang, J. Lee and K. Y. Park, "Deoenjang Extract Has Anticancer Activity and Induces Apoptosis in AGS Human Gastric Adenocarcinoma," Journal of Food Science and Nutrition, Vol. 10, 2005, pp. 167-171. doi:10.3746/jfn.2005.10.2.167

[10] B. Y. Jeon, H. N. Seo, A. Yun, I. H. Lee and D. H. Park, "Effect of Glasswort (Salicornia herbacea L.) on Nuruk-Making Process and Makgeolli Quality," Food Science and Biotechnology, Vol. 19, 2010, pp. 999-1004. doi:10.1007/s10068-010-0140-9 
[11] H. N. Seo, B. Y. Jeon, A. Yun and D. H. Park, "Effect of Glasswort (Salicornia herbacea L.) on Microbial Community Variation in the Vinegar-Making Process and Vinegar Characteristics," Journal of Microbiology and Biotechnology, Vol. 20, No. 9, 2010, pp. 1322-1330. doi:10.4014/jmb.1003.03041

[12] US Department of Agriculture, "USDA National Nutrient Database for Standard Reference, Release 24," 2012. http://www.ars.usda.gov/Services/docs.htm?docid=8964

[13] L. E. Erickson, I. G. Minkevich and V. K. Eroshin, “Application of Mass and Energy Regularities in Fermentation," Biotechnology and Bioengineering, Vol. 20, No. 10, 2004, pp. 1595-1621. doi:10.1002/bit.260201008

[14] H. C. Chen, "Optimizing the Concentration of Carbon, Nitrogen and Phosphorus in a Citric Acid Fermentation with Response Surface Method," Food Biotechnology, Vol. 10, 1996, pp. 13-27. doi: 10.1080/08905439609549898

[15] A. Derrien, L. J. M. Coiffard, C. Coiffard and Y. RoeckHoltzhauer, "Free Amino Acid Analysis of Five Microalgae," Journal of Applied Phycology, Vol. 10, No. 2, 1998, pp. 131-134. doi:10.1023/A:1008003016458

[16] O. S. Ijarotimi and A. J. Olopade, "Determination of Amino Acid Content and Protein Quality of Complementary Food Produced from Locally Available Food Materials in Ondo State, Nigeria," Malaysian Journal of Nutrition, Vol. 15, 2009, pp. 87-95.

[17] X. Wang, A. Lásztity, M. Viczián, Y. Israel and R. M. Barne, "Inductively Coupled Plasma Spectrometry in the Study of Childhood Soil Ingestion," Journal of Analytical Atomic Spectrometry, Vol. 4, 1989, pp. 727-735. doi:10.1039/ja9890400727

[18] M. L. Price and L. G. Butler, "Rapid Visual Estimation and Spectrophotometric Determination of Tannic Content of Sorghum Grain," Journal of Agricultural Food Chemistry, Vol. 25, 1977, pp. 1268-1273. doi:10.1021/if60214a034

[19] G. K. Jayaprakasha, R. P. Singh and K. K. Sakariah, “Antioxidant Activity of Grape Seed (Vitis vinifera) Extracts on Peroxidation Models in Vitro," Food Chemistry, Vol. 73, No. 3, 2001, pp. 285-290. doi:10.1016/S0308-8146(00)00298-3

[20] D. O. Kim, K. W. Lee, H. J. Lee and C. Y. Lee, "Vitamin C Equivalent Antioxidant Capacity (VCEAS) of Phenolic Phytochemicals," Journal of Agricultural Food Chemistry, Vol. 50, No. 13, 2002, pp. 3713-3717. doi:10.1021/jf020071c

[21] S. J. Lee, Y. W Lee, J. Chung, J. K. Lee, J. Y. Lee, D. Jahng, Y. Cha and Y. Yu, "Reuse of Low Concentrated Electronic Wastewater Using Selected Microbe Immobilized Cell System," Water Science and Technology, Vol. 57, No. 8, 2008, pp. 1191-1197. doi:10.2166/wst.2008.246

[22] B. Y. Jeon and D. H. Park, "Effect of Glasswort (Salicornia herbacea L.) and Rice (Oryzae sativa L.) on Quality of Ganjang (Korean Soy Sauce), "Food Science and Biotechnology, Vol. 20, No. 4, 2011, pp. 979-986. doi:10.1007/s10068-011-0135-1
[23] N, Batasundram, K. Sundram and S. Samman, "Phenolic Compounds in Plants and Agri-Industrial By-Products: Antioxidant Activity, Occurance, and Potential Uses," Food Chemistry, Vol. 99, No. 1, 2006, pp. 191-203. doi:10.1016/j.foodchem.2005.07.042

[24] D. Malenčić, Z. Maksimović, M. Popović and J. Miladinović, "Polyphenol Contents and Antioxidant Activity of Soybean Seed Extracts," Bioresearch and Technology, Vol. 99, 2008, pp. 6688-6691. doi:10.1016/j.biortech.2007.11.040

[25] M. Walter and E. Marchesan, "Phenolic Compounds and Antioxidant Activity of Rice," Brazilian Archives of Biology and Technology, Vol. 54, No. 2, 2011, pp. 371-377. doi:10.1590/S1516-89132011000200020

[26] S. S. Ham, K. K. Choi, C. B. Cui, B. G. Lee, D. S. Joo and D. S. Lee, "Quality Characteristics of Commercial Soy Sauce Fermented by Bacillus licheniformis NH20 Isolated from Traditional Meju and Aspergillsu oryzae," Food Science Biotechnology, Vol. 13, 2004, pp. 537-543.

[27] Y. S. Kim, B. H. Oh and D. H. Shin, "Quality Characteristics of Kochujang Prepared with Different Meju Fermented with Aspergillus sp. and Bacillus subtilis," Food Science Biotechnology, Vol. 17, No. 3, 2008, pp. 527 533.

[28] S. S. Ham, K. K. Choi, C. B. Cui, B. G. Lee, D. S. Joo and D. S. Lee, "Quality Characteristics of Commercial Soy Sauce Fermented by Bacillus licheniformis NH20 Isolated from Traditional Meju and Aspergillsu oryzae," Food Science Biotechnology, Vol. 13, 2004, pp. 537-543.

[29] E. L. Kim and S. C. Kang, "Quality Evaluation by the Addition of Pine Needle and Artemisia princeps Extracts in Vinegared Kochjang," Journal of the Korean Society for Applied Biological Chemistry, Vol. 50, 2007, pp. 167177.

[30] B. M. Jung and S. B. Roh, "Physiological Quality Comparison of Commercial Doenjang and Traditional Green Tea Doenjang," Journal of the Korean Society of Food Science and Nutrition, Vol. 33, 2004, pp. 132-139. doi:10.3746/jkfn.2004.33.1.132

[31] S. K. Park and K. I. Seo, "Quality Assessment of Commercial Doenjang Prepared by Traditional Method," Journal of the Korean Society of Food Science and Nutrition, Vol. 29, 2000, pp. 211-217.

[32] H. Rughoonundun, R. Mohee and M. T. Holzapple, "Influence of Carbon-to-Nitrogen Ratio on the Mixed-Acid Fermentation of Wastewater Sludge and Pretreated Bagasse," Bioresource Technology, Vol. 112, 2012, pp. 9197. doi:10.1016/j.biortech.2012.02.081

[33] T. F. Thingstad and R. Lignell, "Theoretical Models for the Control of Bacterial Growth Rate, Abundance, Diversity and Carbon Demand," Aquatic Microbial Ecology, Vol. 13, No. 1, 1997, pp. 19-27. doi:10.3354/ame013019

[34] P. Christen, A. Bramorski, S. Revah and C. R. Soccol, "Characterization of Volatile Compounds Produced by Rhizopus Strains Grown on Agro-Industrial Solid Wastes," Bioresource Technology, Vol. 71, No. 3, 2000, pp. 211215. doi:10.1016/S0960-8524(99)00084-X 

Ingredients and Bacterial Community Diversity in Doenjang (Korean Soybean Paste)

[35] Z. Yanfang and T. Wenyi, "Flavor and Taste Compounds Analysis in Chinese Solid Fermented Soy Sauce," African Journal of Biotechnology, Vol. 8, No. 4, 2009, pp. 673681.

[36] P. J. Spillman, A. P. Pollnitz, D. Liacopoulos, K. H. Pardon and M. A. Setton, "Sefton, Formation and Degradation of Furfuryl Alcohol, 5-Methylfurfuryl Alcohol, Vanillyl Alcohol, and Their Ethyl Ethers in Barrel-Aged Wines," Journal of Agricultural Food Chemistry, Vol. 46, 1998, pp. 657-663. doi:10.1021/jf970559r

[37] I. Blank and L. B Fay, "Formation of 4-Hydroxy-2,5Dimethyl-3(2H)-Furanone and 4-Hydroxy-2(or 5)-Ethyl5(or 2)-Methyl-3(2H)-Furanoned Reaction Based on Pentose Sugars," Journal of Agricultural Food Chemistry,
Vol. 44, 1996, pp. 531-536. doi:10.1021/jf950439o

[38] H. J. Wang and P. A. Murphy, "Isoflavone Contents in Composition in Commercial Soybean Foods," Journal of Agricultural Food Chemistry, Vol. 42, No. 8, 1994, pp. 1666-1673. doi:10.1021/jf00044a016

[39] J. H. Jeong and J. S. Ki, "Studies on the Contents of Free Amino Acids, Organic Acids, and Isoflavones in Commercial Soybean Paste," Journal of the Korean Society of Food Science and Nutrition, Vol. 27, 1998, pp. 10-15.

[40] M. Mikelsaar and M. Zilmer, "Lactobacillus fermentum ME-3 an Antimicrobial and Antioxidantive Probiotic," Microbial Ecology in Health and Disease, Vol. 21, No. 1, 2009, pp. 1-27. doi:10.1080/08910600902815561 